\title{
Unrehydrated Guaiac Test
}

National Cancer Institute

\section{Source}

National Cancer Institute. Unrehydrated Guaiac Test. NCI Thesaurus. Code C74539.

A fecal occult blood test that uses a colorimetric assay to detect fragmented hemoglobin in stool. The assay slides or paper are not hydrated during sample processing. 